UDC 636.2.082.453

(C) 2016

V. Dzitsiuk, Doctor of Agricultural Sciences

The Institute of Animal Breeding and Genetics of M. Zubets

\title{
CYTOGENETIC CHARACTERISTICS OF CATTLE AT DIFFERENT METHODS OF GROWING
}

The purpose. Determination of cytogenetic characteristics of animals at different stages of selection process. Methods. Cultivation of lymphocytes, preparation of cytogenetic specimens, grading and record-keeping of aberrations of chromosomes is realized using standard procedures. Results. It is fixed that in karyotypesof the animals got as a result of interspecific crossings, aberrations of chromosomes were twice more, than at crossing hybrids and purebreds. Conclusions. At building multicomponent breeds of animals cytogenetic features (individual and pedigree) can play the role of genetic marker.

Key words: chromosomes, aberrations, interspecific and breed crossing of animals, cytogenetic marker.

The chromosomal instability of animals is caused by a variety of factors. The main ones are the environmental factors (chemical, radiation background etc), the failure in work of enzymes that are responsible for the integrity of the genome [1], the changes in the repair or replication of chromosomes [3], immunosuppression [5] and other. However, the number of issues in this area is still controversial despite the numerous studies of the reasons of chromosomal mutations.

In particular, the discussions are held concerning the impact of livestock breeding methods on the stability of the karyotype. It is believed that animal crossbreeding, even species that are related yet obtained by different breeding systems in different environmental conditions, leads to the de-consolidation of heredity and to the destruction of adaptive gene complexes. According to Y. Merkurieva, the breeding methods affect the expression of aneuploidy and polyploidy, and perhaps on other karyotype indicators. T. Dobzhansky found the chromosomes with fatal and semi-fatal properties, whose appearance was caused by chromosomal rearrangements [6]. 
According to C. P. Popescu, the interspecific crosses (the hybrids of yak and cattle) have the higher level of numerical chromosome aberrations than the parental species have [9].

D. Zartman and N. Feshheysher [12] found that the animals of Hereford breed have a correlation between polyploidy and the breeding method and selection options. Thus, the lowest somatic and cell ploidy was observed in the group of triple-bred hybrids, and slightly higher one was found in inbred animals.

Akhila K. Sahoo, the researcher from the University of Hyderabad, India, found karyologic features of crossbred animals, conducting a detailed karyometric analysis of two groups of bulls - hybrids of Jersey with Harayan breeds and Holstein with Harayan breeds. Chromosomes of crossbred and purebred animals differed on the relative length of chromosomes and on the ratio of the arms of sex chromosomes [10].

Materials and Methods of of Research. The research of cytogenetic characteristics of the beef breed animals with various blood properties was done. The research was provided in the farms of "Zelenogirske" in Odesa region, PCB "Simferopilske" in Simferopol city district of ARC. These characteristics were received from cross-breed interspecific mating during the creation of the southern beef breed of cattle. The process of getting the samples of chromosomes of peripheral blood lymphocytes of the animals was carried out by a Hanhenford method [7]. The selection of metaphase plates for cytogenetic analysis, classification and registration of chromosomal aberrations were performed by conventional methods.

Results of Research. After the analysis of the chromosomes samples in the karyotypes of all studied animals, the aberrations of chromosomal and of chromatid types were found. The even and individual fragments, shortages, breaks, translocations and the acentric rings were identified among the aberrations of chromosomal type. The chromatid aberrations were generally represented by the breaks and fragments of the separate chromatids.

There was an analysis of the karyotypes of 45 species of southern beef breed 
animals that derived from the various types of crosses. The results displayed that interspecific hybrids (cattle $\times$ zebu) had 1-1.5 times more aberrant cells compared to cross-breed hybrids (Table 1). The aberrations of chromatid type dominated in the karyotypes of hybrid animals, while the animals of Red Steppe breed mostly had aberrations shown as even fragments, breaks of both chromatids and large chromosomes deletions.

Table 1. The frequency of chromosome aberrations in animals of various blood properties during the creation of a southern beef breed

\begin{tabular}{|c|c|c|c|c|c|}
\hline \multirow[b]{2}{*}{ Animals Groups* } & \multirow{2}{*}{$\begin{array}{l}\text { Numbe } \\
\mathrm{r} \text { of } \\
\text { Individ } \\
\text { uals }\end{array}$} & \multirow{2}{*}{$\begin{array}{l}\text { Total } \\
\text { Amount of } \\
\text { Aberrant } \\
\text { Metaphases } \\
\text {, \% }\end{array}$} & \multicolumn{3}{|c|}{ Amount of Aberrations, \% } \\
\hline & & & Genome & $\begin{array}{l}\text { Chromo } \\
\text { some }\end{array}$ & $\begin{array}{l}\text { Chromat } \\
\text { id }\end{array}$ \\
\hline $\begin{array}{l}\text { Hybrids } \mathrm{Z} \times \mathrm{CRS} \text { (incl. } 3 / 8 \\
\mathrm{Z} \times 1 / 2 \mathrm{C} \times 1 / 2 \mathrm{H} \times 1 / 4 \mathrm{RS} \text { ) }\end{array}$ & 16 & $29,1 \pm 1,4$ & $8,2 \pm 2,4$ & $\begin{array}{l}10,7 \pm 2 \\
6\end{array}$ & $15,8 \pm 1,5$ \\
\hline Hybrids $3 / 4 \mathrm{Zebu} \times 1 / 4 \mathrm{C} \times 1 / 8 \mathrm{RS}$ & 9 & $30,2 \pm 2,3$ & $5,8 \pm 2,7$ & $9,5 \pm 2,5$ & $16,2 \pm 1,8$ \\
\hline Hybrids $1 / 2 \mathrm{H} \times 1 / 2 \mathrm{RS}$ & 8 & $16,4 \pm 2,0$ & $6,4 \pm 2,8$ & $8,6 \pm 2,0$ & $10,9 \pm 1,7$ \\
\hline Hybrids $1 / 2 \mathrm{C} \times 1 / 2 \mathrm{RS}$ & 12 & $18,7 \pm 1,8$ & $9,2 \pm 3,0$ & $8,3 \pm 1,9$ & $9,3 \pm 2,0$ \\
\hline Red Steppe Breed & 11 & $15,1 \pm 1,8$ & $7,5 \pm 2,8$ & $9,1 \pm 1,8$ & $3,10 \pm 0,5$ \\
\hline
\end{tabular}

*Z - Zebu;

C - Charolais Breed;

RS - Red Steppe Breed;

$\mathrm{H}$ - Holstein Breed.

According to N. Bochkov and his colleagues [2], the proportion of chromatid type aberrations prevailed in spontaneous mutagenesis, and aberrations of chromosome type dominated under radiation effects. The data on the increase of amount of chromatid type aberrations during the process of creation of the breed shows that such aberrations are non-accidental and the environmental factors can not be the cause of their occurrence. 
As the results of studies it was stated that there is a pattern of localization of chromosome and chromatid breaks due to the size of the chromosome. It was established that most of the breaks were found in large chromosomes (the first group) the least of them were in the smallest chromosomes, the ones of the first group (Table 5). For separate animals it was found that there is a domination of chromatid breaks of the largest chromosome, in other examples there were chromatid breaks of acrocentric middle-sized chromosomes.

Table 2. Participation of the Chromosomes of Various Groups in the Aberrations

\begin{tabular}{|c|c|c|c|c|c|c|c|}
\hline \multirow[b]{2}{*}{ Groups of Animals } & \multirow{2}{*}{$\begin{array}{l}\text { Num } \\
\text { ber } \\
\text { of } \\
\text { Indiv } \\
\text { idual } \\
\text { s }\end{array}$} & \multirow{2}{*}{$\begin{array}{l}\text { Total } \\
\text { Amount } \\
\text { of } \\
\text { Researc } \\
\text { hed } \\
\text { Metaph } \\
\text { ases } \\
\end{array}$} & \multirow{2}{*}{$\begin{array}{l}\text { Total } \\
\text { Amount } \\
\text { of } \\
\text { Aberrant } \\
\text { Metaphas } \\
\text { es, \% }\end{array}$} & \multicolumn{4}{|c|}{$\begin{array}{l}\text { Participation of the Chromosomes of } \\
\text { Various Groups in the Aberrations }\end{array}$} \\
\hline & & & & $\begin{array}{l}\text { I Group } \\
\text { (Pairs } \\
1-4)\end{array}$ & $\begin{array}{l}\text { II Group } \\
\text { (Pairs 5- } \\
20 \text { ) }\end{array}$ & $\begin{array}{l}\text { III } \\
\text { Group } \\
\text { (Pairs } \\
\text { 21-29) }\end{array}$ & $\begin{array}{l}\mathrm{X}-\mathrm{Y} \\
\text { Chromoso } \\
\text { mes }\end{array}$ \\
\hline $\begin{array}{l}\text { Southern Beef } \\
\text { Breed } \\
\text { («Zelenohirske» } \\
\text { Ltd. in Odesa } \\
\text { Region) }\end{array}$ & 40 & 2160 & $28,5 \pm 1,5$ & $\begin{array}{l}48,0 \pm 3 \\
6\end{array}$ & $36,5 \pm 3,9$ & $\begin{array}{l}15,5 \pm 4 \\
1\end{array}$ & Not Found \\
\hline $\begin{array}{l}\text { Southern Beef } \\
\text { Breed } \\
\text { ("Simferopolske" in } \\
\text { ARC) }\end{array}$ & 11 & 960 & $32,7 \pm 5,2$ & $\begin{array}{l}51,9 \pm 4 \\
5\end{array}$ & $35,0 \pm 3,0$ & $\begin{array}{l}13,0 \pm 2, \\
5 \text { Not } \\
\text { Found }\end{array}$ & Not Found \\
\hline Red Steppe Breed & 11 & 850 & $15,1 \pm 2,6$ & $\begin{array}{l}41,3 \pm 3 \\
7\end{array}$ & $40,5 \pm 4,8$ & $\begin{array}{l}18,2 \pm 3 \\
2\end{array}$ & Not Found \\
\hline
\end{tabular}

The results displayed the chromosomes of the first group were damaged the most, moreover, the bigger part was represented by the chromatid type aberrations. Thus, the animals of Southern beef breed had 54\% of first-group chromosomal breaks (mostly of the first chromosome) among all aberrations of this type. This approves the fact that the frequency of constitutional chromosomal abnormalities is distributed proportionally to 
the length of karyotype chromosomes [11].

The chromosomes of the third group rarely have the breaks, however they do so more often than the large ones. They are involved in asynchronous cleavage of centromeric regions of chromosomes (ACCRC) and in aneuploidy. The aberrations in small chromosomes are usually not found. However, the small chromosomes participate in asynchronous cleavage of centromeric regions of chromosomes more often comparing to the large chromosomes. The fraction of third and the sixths chromosomes is small (according to the researches by other authors, they are often involved in chromosomal aberrations in animals that have the radiation damage of cells), which indicates the nonenvironmental cause of mutagenesis in studied animals [8].

\section{Conclusions.}

For now, the cytogenetic picture of selection processes remains incomplete. And the attention of the breeders is not drawn to the peculiarities of cytogenetic characteristics of individuals involved in the selection process. However, it is advisable to note that during the creation of complex multicomponent breeds of animals, both individual and breed-related animals are capable of acting as genetic markers. The researches of nuclear structures of somatic cells are able to value the condition of the hereditary apparatus of the animal organism in connection with varying productiveness, also to identify the mechanisms that lead to a decrease in fertility, which often comes along with intense selection by other indicators. And the researches may eliminate the cause of that. Cytogenetic techniques can point to new sources of genetic variation, and, what is particularly important, they can prevent from spreading of harmful chromosomal aberrations in the populations of animals.

\section{Bibliography}

1. Akyf'ev A.P., Khandohyna E.K., Mutovyn H.R. Khromosomnыy mutahenez pry nasledstvennыkh boleznyakh cheloveka s narushennoy reparatsyey DNK. Usp. henetyky, 1984, 12: 182-219 
2. Bochkov N. P., Kuleshov N. P., Zhurkov V. S. Analyz spontannыkh khromosomnыkh aberratsyy v kul'ture lymfotsytov cheloveka / N. P. Bochkov, N. P. Kuleshov, V. S. Zhurkov // Tsytolohyya. — 1972. — №14. — S. 1267-1273.

3. Dubynyn N.P. Hennaya teoryya zlokachestvennoho rosta. Usp. sovr. byol., 1984, 57(2): 163-178

4. Merkur"yeva E. K. Henetyka s osnovamy byometryy / E. K. Merkur"yeva, H. N. Shanhyn-Berezovskyy. -— M. : Kolos. — 1983. — 400 s

5. Skorova S.V. Vlyyanye ymmunolohycheskykh reaktsyy orhanyzma na chastotu strukturnokh mutatsyy khromosom. Avtoref. kand. dys. Novosybyrsk, 19826. Dobzhansky T. Genetics and the Origin of Species / T.Dobzhansky // N.Y. : Columbia University Press, 1937. — 98 p.

7. Hungerford D.A. Leucocytes cultured from small inocula of whole blood and preparation methaphase chromosomes by treatment with hypotic $\mathrm{KCl} / /$ Stain Techn. - 1965. - V. 40.- P. 333-338

8. Morad M., Jonasson J. Distribution of mitomycin induced breaks on human chromosomes / M. Morad, J. Jonasson // Heriditas. — 1973. — V. 74. — P. 273282.

9. Popescu C. P. Chromosomes of the cow and bull / C. P. Popescu // Adv.Sci.and Comp.Med. - 1990. - V.34. — P. 41-71.

10. Sahoo A. K. Cytogenetic studies on the metaphase chromosomes in the taurusindicus crossbred breeding bulls / A. K. Sahoo, G. Choudhuri, N. Koley, S. K. Ghosh // Indian J.Anim.Health. — 1992. — V.31, №2. — P. 1-10

11. Vogel F. Humah genetics: Problem and approches / F. Vogel, A. G. Motulsky // Spengler-Verlag.-Berlin.-German. -1996. — T. 22, № 1. — C. 67-72. 
12. Zartman D. I. Somatic aneuploidy and polyploidy in inbred and linecross cattle / D. I. Zartman, N. S. Fechheimer // J. Anim.Sci. — 1967. - V. 26, № 3. P. 678-682 